\title{
The Influence of SPS Compaction Pressure onto Mechanical Properties of Al-20Si-16Fe Alloy Prepared by Mechanical Alloying
}

Filip Průša ${ }^{1}$, Gillet Oceáne ${ }^{1}$, Adriana Bernatikováa ${ }^{1,2}$, Slawomir Cygan ${ }^{3}$

${ }^{1}$ Faculty of Chemistry and Technology, University of Chemistry and Technology Prague, Technická 5, 16628 Prague 6. Czech Republic. E-mails: prusaf@vscht.cz; oceane.gillet@etu.unilim.fr;

${ }^{2}$ Institute of Physics of the Czech Academy of Sciences, Na Slovance 1999/2, 18221 Prague 8. Czech Republic. E-mail: bernatikova@fzu.cz

${ }^{3}$ The Institute of Advanced Manufacturing Technology, Wroclawska 37A, 30-011 Krakow, Poland. E-mail: slawomir.cygan@ios.krakow.pl

The Al-20Si-16Fe alloy (wt.\%) was prepared by a combination of short-term mechanical alloying and consequential compaction via spark plasma sintering. The compaction was done at two different pressures of 80 MPa and 6 GPa to describe the influence of pressure onto a resulting properties of prepared alloy. The microstructure of both the prepared compact alloys showed presence of sub-micrometre particles embedded in the Al-matrix while some residual porosity was also observed. This corresponded to the lower compaction pressure of only 80 MPa, which, in comparison to the $6 \mathrm{GPa}$ allowed to retain some porosity. The higher compaction pressure of 6 GPa resulted in a increase of the compressive strength of 1426 MPa while the hardness was slightly lower reaching still high 348 HV 5. On the other hand, the sample compacted by a pressure of $80 \mathrm{MPa}$ reached compressive strength of 758 MPa while showing higher hardness of 411 HV 5. The difference in the observed properties can be attributed to a different compaction temperatures of $500^{\circ} \mathrm{C}$ (for $80 \mathrm{MPa}$ ) and of approximatelly $600^{\circ} \mathrm{C}$ (for $\left.6 \mathrm{GPa}\right)$.

Keywords: Mechanical alloying, spark plasma sintering, mechanical properties, microstructure.

\section{Acknowledgement}

The research was supported by the Czech Science Foundation (project no. P108/12/G043) and partially by the COST Action CA15102.

\section{References}

[1] UZUN, O., KILICASLAN, M.F., Y1LMAZ, F. (2014). Formation of novel flower-like silicon phases and evaluation of mechanical properties of hypereutectic melt-spun Al-20Si-5Fe alloys with addition of V. In: Materials Science and Engineering: A, Vol. 607, No. 0, pp. 368-375.

[2] KILIÇASLAN, M.F., YILMAZ, F.; et al. (2013). Microstructure and microhardness of melt-spun Al-25Si-5FeXCo (X\&\#xa0;=\&\#xa0;0, 1, 3, 5) alloys. In: Materials Characterization, Vol. 77, No. 0, pp. 15-22.

[3] FATIH KILICASLAN, M., YILMAZ, F.; et al. (2012). Effect of Co on Si and Fe-containing intermetallic compounds (IMCs) in Al-20Si-5Fe alloys. In: Materials Science and Engineering: A, Vol. 556, No. 0, pp. 716-721.

[4] CAI, Y., LIANG, R.; et al. (2011). Effect of $\mathrm{Cr}$ and $\mathrm{Mn}$ on the microstructure of spray-formed $\mathrm{Al}-25 \mathrm{Si}-5 \mathrm{Fe}-3 \mathrm{Cu}$ alloy. In: Materials Science and Engineering: A, Vol. 528, No. 12, pp. 4248-4254.

[5] MORETO, J.A., MARINO, C.E.B.; et al. (2014). SVET, SKP and EIS study of the corrosion behaviour of high strength Al and Al-Li alloys used in aircraft fabrication. In: Corrosion Science, Vol. 84, No. 0, pp. 30-41.

[6] DURSUN, T., SOUTIS, C. (2014). Recent developments in advanced aircraft aluminium alloys. In: Materials \& Design, Vol. 56, No. 0, pp. 862-871.

[7] AMIRKHANYAN, L., WEISSBACH, T.; et al. (2014). Thermodynamic investigation of the -Al-Fe-Si intermetallic ternary phase: A density-functional theory study. In: Journal of Alloys and Compounds, Vol. 598, No., pp. $137-141$.

[8] PRŮŠA, F., BLÁHOVÁ, M.; et al. (2016). High-Strength Ultra-Fine-Grained Hypereutectic Al-Si-Fe-X (X = Cr, Mn) Alloys Prepared by Short-Term Mechanical Alloying and Spark Plasma Sintering. In: Materials, Vol. 9, No. 12, pp. 973.

[9] PRŮŠA, F., VOJTĚCH, D.; et al. (2015). Structure and mechanical properties of Al-Si-Fe alloys prepared by short-term mechanical alloying and spark plasma sintering. In: Materials \& Design, Vol. 75, No., pp. 65-75. 
[10] PRŮŠA, F., VOJTĚCH, D. (2013). Mechanical properties and thermal stability of Al-23Si-8Fe-1Cr and Al-23Si8 Fe-5Mn alloys prepared by powder metallurgy. In: Materials Science and Engineering: A, Vol. 565, No. 0, pp. 13-20.

[11] PRŮŠA, F., VOJTĚCH, D., DÁM, K. (2012). Characterization of the Al-13Si-10Fe alloy produced by centrifugal atomization and ultra-high-pressure compaction. In: Kovove Materialy, Vol. 50, No. 6, pp. 399-406.

[12] KUČERA, V., PRŮŠA, F., VOJTĚCH, D. (2016). Processing of Al-Fe Scraps by Powder Metallurgy. In: Manufacturing Technology, Vol. 16, No. 4, pp. 726-732.

[13] KUČERA, V., PRŮŠA, F., VOJTĚCH, D. (2016). Processing of aluminium alloys with high content of iron by methods of powder metallurgy. In: Manufacturing Technology, Vol. 16, No. 5, pp. 978-984.

[14] PRŮŠA, F., VOJTECH, D.; et al. (2015). Mechanical alloying: A way how to improve properties of aluminium alloys. In: Manufacturing Technology, Vol. 15, No. 6, pp. 1036-1043.

\section{Paper number: M2017182}

Copyright (C) 2017. Published by Manufacturing Technology. All rights reserved. 